\title{
Are red mullet efficient as bio-indicators of mercury contamination? A case study from the French Mediterranean
}

\author{
Cresson Pierre ${ }^{1,2, *}$, Bouchoucha Marc ${ }^{1}$, Marco-Miralles Francoise ${ }^{1}$, Elleboode Romain ${ }^{2}$, \\ Mahe Kelig $^{2}$, Marusczak Nicolas ${ }^{1,5}$, Thebault Herve ${ }^{3}$, Cossa Daniel ${ }^{1,4}$
}

1 IFREMER, Centre de Méditerranée, CS 20330, F-83507 La Seyne sur Mer, France

2 IFREMER, Centre Manche - Mer du Nord, BP 669, F-62321 Boulogne sur Mer, France

3 Institut de Radioprotection et de Sûreté Nucléaire, PRP-ENV/SESURE/LERCM, CS 20330, F-83507

La Seyne sur Mer, France

${ }^{4}$ ISTerre, Université Joseph Fourier, BP 53, F-38041 Grenoble, France

${ }^{5}$ Observatoire Midi-Pyrénées, Laboratoire Géosciences Environnement Toulouse,

CNRS/IRD/Université Toulouse III, 14 avenue Edouard Belin, 31400 Toulouse, France

* Corresponding author : Pierre Cresson, Tel.: +33 3219956 17. ;

email address : pierre.cresson@ifremer.fr

\begin{abstract}
:
Mercury $(\mathrm{Hg})$ is one of the main chemicals currently altering Mediterranean ecosystems. Red mullet (Mullus barbatus and M. surmuletus) have been widely used as quantitative bio-indicators of chemical contamination. In this study, we reassess the ability of these species to be used as efficient bioindicators of $\mathrm{Hg}$ contamination by monitoring during 18 months $\mathrm{Hg}$ concentrations in muscle tissue of mullet sampled from 5 French Mediterranean coastal areas. Mean concentrations ranged between 0.23 and $0.78 \mu \mathrm{g} \mathrm{g}-1$ dry mass for both species. Values were consistent with expected contamination patterns of all sites except Corsica. Results confirmed that red mullets are efficient bio-indicators of $\mathrm{Hg}$ contamination. Nevertheless, the observed variability in $\mathrm{Hg}$ concentrations calls for caution regarding the period and the sample size. Attention should be paid to environmental and biologic specificities of each studied site, as they can alter the bioaccumulation of $\mathrm{Hg}$, and lead to inferences about environmental $\mathrm{Hg}$ concentrations.
\end{abstract}




\section{Graphical abstract}

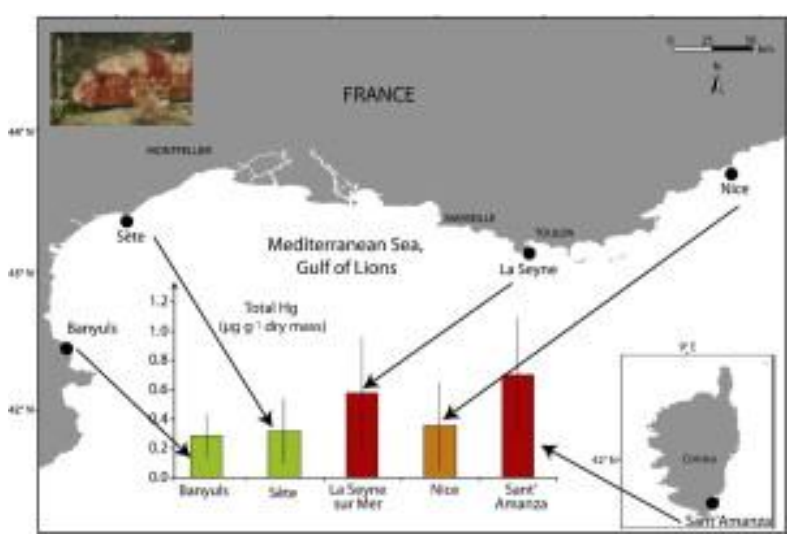

\section{Highlights}

- Hg was monitored in Mullus spp. from 5 French Mediterranean zones during 18 months. All concentrations were below recommended European health safety levels. $\mathrm{Hg}$ trends were consistent with environmental contamination except in Corsica. Oligotrophy could explain the high and unexpected values in Corsica. Biotic and abiotic parameters must been considered when using bioindicators.

Keywords : Mercury, Bio-indicator, Fish, Mullus spp., Mediterranean 


\section{Introduction}

Chemical contamination is one of the main threats currently causing alteration to marine ecosystems (Halpern et al., 2008), with observed impact on individuals, populations, species and ecosystems (Fleeger et al., 2003). Chemical pressure is high in the Mediterranean Sea, a semi-enclosed sea surrounded by highly industrialized and densely populated countries (Durrieu de Madron et al., 2011). Among all chemicals, mercury (Hg) is of great concern, as it has neurotoxic, immunotoxic and teratogenic effects on vertebrates (Scheuhammer et al., 2007; Tartu et al., 2013). Metallic mercury $\left(\mathrm{Hg}^{0}\right)$ is emitted in the environment from natural (mainly volcanic emissions) and anthropogenic sources, with an increase in the anthropogenic sources since the end of the $18^{\text {th }}$ century (Streets et al., 2011). $\mathrm{Hg}^{0}$ is highly volatile and can be transported during long periods of time and over long distances. After deposition as $\mathrm{Hg}^{\mathrm{II}}$, $\mathrm{Hg}$ is methylated by heterophic bacteria as methylmercury (MeHg). In marine environments, this process occurs in low oxygen zones in the water column, and at the water/sediment interface (Blum et al., 2013; Cossa et al., 2009; Heimbürger et al., 2010). MeHg is the chemical form of $\mathrm{Hg}$ of greatest concern, as it can enter the trophic networks after being uptaken by the phytoplankton. High MeHg concentrations are observed in high trophic level species, due to the high level of biomagnification of MeHg throughout the trophic networks. To cope with such high Hg concentrations, physiological mechanisms were developed against the adverse effect of metallic contaminants. The synthesis of metallothionein is commonly proposed as an important detoxifying mechanism in fishes. Metallothionein is a class of low molecular-weight proteins able to bind to metals and to play a role in the detoxifying process as high metallothionein concentration are measured in fish sampled in contaminated zones (Filipović and Raspor, 2003; .Zorita et al. 2009). Others detoxifying mechanisms can involve antioxidant synthesis or metabolisation of contaminants in the liver (Company et al. 2010).

Monitoring Hg contamination can by performed by assessing environmental concentrations in water or sediment. This approach produces an immediate measure of contamination in a specific place but is complex to use, mainly due to low concentrations and the high temporal and spatial variability observed. In addition, high contaminant concentrations in the environment do not always lead to high values and adverse effects on organisms and viceversa (Beyer et al., 1996; Martínez-Gómez et al., 2012). Consequently, in most cases, contamination has been assessed by bio-monitoring, i.e. inferring the contamination in the environment from values measured in organisms. This approach can provide time and space integrated information about the actual Hg contamination, and also about the bio-available 
fraction of the contaminant, which actually enters the trophic networks. Determining Hg concentrations in marine organisms is also required for sanitary purpose, as consumption of contaminated products is the main pathway leading to human intoxication (Endo et al., 2013; Martí-Cid et al., 2007). Nevertheless, this approach is rendered complex because of the influence of various biotic and abiotic factors on the bioaccumulation (Phillips and Rainbow, 1998).

Red mullet (Mullus spp.) exhibit several features allowing them to be considered as appropriate bio-indicators of mercury contamination. These species are observed off all Mediterranean shores, providing a basis for wide-ranging geographical comparison of the results (Kucuksezgin et al., 2001; Labropoulou et al., 1997; Lombarte et al., 2000; Morat et al., 2012; Reñones et al., 1995; Tserpes et al., 2002). The biological and ecological features of this species, such as diet, growth, spatial patterns and reproduction have been extensively studied and may provide a basis for explaining the contamination patterns observed (BautistaVega et al., 2008; Cresson et al., 2014 a,b; Labropoulou et al., 1997; Lombarte et al., 2000; Machias et al., 1998; Machias and Labropoulou, 2002; Morat et al., 2012; Reñones et al., 1995). Since food is considered to be the main source of Hg contamination in fish (Hall et al., 1997), a good knowledge of dietary habits is crucial to the understanding of contamination patterns. Both M. barbatus and M. surmuletus have similar mesocarnivorous diets based on benthic invertebrates, such as crustaceans and annelids (Bautista-Vega et al., 2008; Cresson et al., 2014b; Labropoulou et al., 1997; Machias and Labropoulou, 2002). With increasing size, M. barbatus changes its diet, consuming larger shrimps and annelids and avoiding small crustaceans. In contrast, $M$. surmuletus has the same diet whatever the size (Bautista-Vega et al., 2008; Labropoulou et al., 1997). Mullus species are considered to be rather territorial (Morat et al., 2012), even if spatial and depth segregation between large and small individuals has been reported (Lombarte et al., 2000). Due to their strong benthic affinity, their burrowing activity and the low range of movement of these species, the level of contamination in Mullus spp can be considered representative of the local contamination level in the environment. These species are also expected to accumulate pollutants at a higher rate than other fish species (Zorita et al., 2008) and were recommended as suitable species for the monitoring of environmental contamination (UNEP/RAMOGE 1999). Finally, these species have a commercial value and have been fished mainly by small-scale coastal fisheries since Roman and Greek antiquity (FAO, 2012; Leleu et al., 2014; Tipton, 2008; Tserpes et al., 2002). For the French Mediterranean, red mullet annual catches ranged between 280 and 500 metric tons 
before 1990 and decreased to nearly 200 t in recent years (FishStatJ, FAO). A high Hg concentrations in muscle tissue of fish could thus represent a concern for human health. As a consequence, Hg concentrations have been extensively surveyed in Mullus surmuletus and M. barbatus throughout the Mediterranean Sea (Capelli et al. 2004; Conti et al., 2012; Copat et al., 2012; Corsi et al., 2002; Falcó et al., 2006; Harmelin-Vivien et al., 2009; Kucuksezgin et al., 2001; Martínez-Gómez et al., 2012). But as previously observed by Dierking et al (2009), most of the studies on contamination in fish were carried out over a single area, where contamination was expected to be high. Similarly, papers comparing Hg concentration in $M$. barbatus and M. surmuletus are scarce (e.g., Harmelin-Vivien et al., 2009) and no data are available regarding temporal variations of $\mathrm{Hg}$ content of the fish tissue. Finally, no study has investigated Hg concentration in fishes from Corsica. Consequently, on the basis of sampling of M. barbatus and M. surmuletus from five French Mediterranean coastal zones during 18 months, we assessed temporal and spatial patterns of Hg concentrations in Mediterranean red mullet muscle, and determined to what extent these species can be considered as good quantitative bio-indicators of $\mathrm{Hg}$ contamination of their surrounding environment.

\section{Materials and methods}

\section{Sample collection and preparation}

Individuals of the two main Mediterranean mullid species (Mullus barbatus barbatus Linnaeus, 1758, hereafter M. barbatus and Mullus surmuletus Linnaeus, 1758) were collected every two months from June 2012 to December 2013 by fishermen operating trammel nets in shallow ( 20 - 50 m depth) coastal waters of the French Mediterranean (Fig. 1), at two sites in the Gulf of Lions (Banyuls-sur-Mer, hereafter Banyuls, and Sète), two in the Provence area (La Seyne-sur-Mer, hereafter La Seyne, and Nice) and one in south-eastern Corsica (Sant’Amanza).

These sites were chosen as they were thought to reflect different levels of contamination: Corsica is considered to be lightly impacted by contamination pressure, and is commonly used as the reference site in contamination studies (e. g. Andral et al., 2004; Lafabrie et al., 2007; Pergent-Martini, 1998). The pattern is similar at Banyuls and Sète, situated away from large cities and harbors. Low Hg concentrations measured in sediment (Ifremer Chemical Contamination Monitoring Network, Table S1) and in fish (Dierking et al., 2009) at these sites are consistent with a low chemical contamination in these sites. On the other hand, fishes 
from La Seyne were caught in the bay of Toulon, one of the major Hg hotspots in the French Mediterranean (Andral et al., 2004; Tessier et al., 2011). Similarly, Hg concentrations are high in Nice harbor sediments and mussels (Andral et al., 2004) but fishes were collected outside this harbor and could thus been considered as less impacted by this contamination. At each location, fishermen were asked to collect at least $2 \mathrm{~kg}$ of fish. In order to ensure that the sampling was representative of the actual catches, they received no further instruction. Mainly, they were asked to fish in the zone where they usually work, and not to balance the sampling if one species appeared predominant. If necessary, fishes were caught in several fishing operations performed throughout the month and were stored frozen until the total quantity reached $\sim 2 \mathrm{~kg}$.

In the lab, species were separated. Individuals were measured (standard length, to the nearest $\mathrm{mm}$ ), weighed (total mass, to the nearest $0.1 \mathrm{~g}$ ) and dissected. A sample of muscle located on the caudal peduncle was collected for total $\mathrm{Hg}$ analysis, as required by the international standards (Nakhlé et al., 2007). Muscle samples were stored frozen, before freeze-drying and grinding. Sagittal otoliths were removed from the cranial cavity to determine fish age.

\section{Mercury determination}

Total Hg concentration was determined by the semi-automated atomic absorption spectrophotometer (AMA-254, Altec Ltd., Praha, Czech Republic) in three steps. First, the muscle sample is burnt and mercury is volatilized. Then the evaporated elemental mercury is captured by a gold trap. Finally, the trap is heated $\left(800^{\circ} \mathrm{C}\right)$, Hg swept into the flow cell, and Hg content is determined by spectrophotometric atomic absorption. The accuracy of the analysis is assessed with a standard certified material (DORM-4, National Research Council of Canada) chosen in accordance with the assumed Hg content of the sample. Certified material is tested for every ten fish samples. Measured values were always within the confidence limits of the certified materials (certified values: $0.410 \pm 0.055 \mu \mathrm{g} \mathrm{g}^{-1}$; found values: $0.386 \pm 0.009 \mu \mathrm{g} \mathrm{g}^{-1}$ ). This technique allows the determination of the total Hg but not the methylmercury (MeHg), the organic mercury compound of major concern. However, total $\mathrm{Hg}$ is a good proxy of MeHg, as MeHg represents 80 to $100 \%$ of the total Hg in Mullus spp. (Storelli et al., 2005; Tolga Gonul and Kucuksezgin, 2007). Concentrations are expressed relative to the dry mass $(\mathrm{dm})$ of individuals. One determination of Hg concentration was performed for each individual. 


\section{Age determination}

As recommended by international expert groups (ICES, 2012) and described in Mahé et al. (2013), two techniques were used in order to achieve the most precise estimation of the fish age: observation under transmitted light, as well as observation under reflected light before and after burning the whole otolith. After preparation, otoliths were immersed in $5 \%$ alcohol water. Otoliths were observed with a binocular microscope connected to a computer with TNPC software (digital processing of calcified structures, www.tnpc.fr). Each otolith was analyzed by three different experts. Age was determined for 917 individuals.

\section{Numerical analyses}

Statistical analyses were run to test (1) spatial differences of length for each species, (2) if a correlation was apparent between length and Hg concentration, and (3) to test the effect of species, fish age, sampling site and time on Hg concentration. Finally, as age could not be determined for all individuals, effect of age on Hg concentration was tested separately. Comparison of mean length between sites and considering both species separately were performed with Kruskall-Wallis non-parametric test (KW), as lengths were not normally distributed. The effect of length on Hg concentration was determined for each species separately by linear Pearson correlation. The general pattern for each species (ie without considering spatial variation) was tested first. Then, spatial differences were tested by considering all sites separately.

The effect of species, sites and sampling dates on Hg concentration was assessed using analysis of variance (ANOVA), as no effect of length on Hg concentration was detected. The effect of age on $\mathrm{Hg}$ concentration was tested first on all individuals together, then considering species and sites separately. Individuals aged 0 and 4 were poorly represented (always less than 3 individuals for each species at each site) and were consequently not included when species and sites were separated.

All ANOVAs were run on log-transformed Hg concentration, as Hg was not normally distributed. When significant differences were observed, Student’s Least Square Distance (LSD) post hoc test was performed. Numerical analyses were run with R statistical software (R Core Team, 2014).

\section{Results}




\section{Sample size, biometry and age}

A total of 1042 fishes were captured, including 556 Mullus surmuletus and 486 M. barbatus. M. surmuletus was the predominant species at all sites except at Nice (Table 1). The actual number of fishes by species, site and date is detailed in Table S2. Individuals aged 1 and 2 years represent $90 \%$ of the sampling (496 and 328 respectively), followed by individuals aged 3 (69). Individuals aged 0 and 4 years were under-represented (22 and 2 respectively). Significant differences of fish length between sites were observed for M. barbatus (KW $\left.\mathrm{H}_{(4,486)}=168.78, \mathrm{p}<0.0001\right)$ and $M$. surmuletus $\left(\mathrm{KW} \mathrm{H}_{(4,556)}=56.65, \mathrm{p}<0.0001\right)$. At similar ages, $M$. barbatus individuals from Sant'Amanza were always larger than counterparts from all other sites (Fig. S1). This trend was not observed for M. surmuletus.

\section{Mercury concentrations}

All measured Hg concentrations were lower than the $2.5 \mu \mathrm{g} \mathrm{g}^{-1}(\mathrm{dm})$ threshold defined by the European Commission as a safety value for mercury concentration in foodstuffs (EC, 2006). Three individuals exhibited concentrations above $2 \mu \mathrm{g} \mathrm{g}^{-1}$, and 15 between 1.5 and $2 \mu \mathrm{g} \mathrm{g}^{-1}$ (Fig. 2). Most of these Hg-rich fishes were M. surmuletus captured at Sant'Amanza (8 individuals) and individuals of both species from La Seyne (5 individuals).

Average Hg concentrations ranged between $0.23 \pm 0.19 \mu \mathrm{g} \mathrm{g}^{-1} \mathrm{dm}$ and $0.78 \pm 0.36 \mu \mathrm{g} \mathrm{g}^{-1} \mathrm{dm}$ with significant differences between sites (Table S3). Higher Hg concentrations were measured at Sant'Amanza and at La Seyne (ANOVA $\left.F_{(4,989)}=82.26, \mathrm{p}<0.0001\right)$. A significant variation of $\mathrm{Hg}$ content was observed between M. surmuletus $\left(0.46 \pm 0.33 \mu \mathrm{g} \mathrm{g}^{-1}\right.$, $\mathrm{dm})$ and $M$. barbatus $\left(0.34 \pm 0.28 \mu \mathrm{g} \mathrm{g}^{-1} \mathrm{dm}\right.$; ANOVA $\left.F_{(1,986)}=12.03, \mathrm{p}<0.001\right)$. This trend appeared to be largely driven by the discrepancy in Hg concentration occurring at Sant'Amanza between M. barbatus (0.33 $\left.\pm 0.27 \mu \mathrm{g} \mathrm{g}^{-1} \mathrm{dm}\right)$ and $M$. surmuletus $(0.76 \pm$ $0.36 \mu \mathrm{g} \mathrm{g}^{-1} \mathrm{dm}$ ), since no significant difference was detected when excluding fishes from Corsica $\left(\right.$ ANOVA F $\left._{(1,986)}=0.20, \mathrm{p}=0.66\right)$.

Temporal variations of Hg concentration were detected (Table S3). Considering both species together, the highest values were measured in April 2013. High values were also observed during spring or summer when separating species and sites (Fig. 3). The highest values were observed in April for M. barbatus at Nice, in June for both species at Sète, in June and August for M. surmuletus at La Seyne and in August for M. surmuletus at Sant'Amanza. In addition, this trend is repeated from one year to another when data are available on both years. For example, at La Seyne, concentrations measured for M. surmuletus in June 2012 (0.99 
$\left.\pm 0.58 \mu \mathrm{g} \mathrm{g}^{-1}\right)$ and in August $2013\left(0.81 \pm 0.33 \mu \mathrm{g} \mathrm{g}^{-1}\right)$ were higher than all other concentrations measured for this species at this site.

\section{Correlations between $\mathrm{Hg}$, length and age}

Length and Hg concentration were poorly correlated (Fig. 4; Table S4). Regarding age, a significant (ANOVA $\left.\mathrm{F}_{(4,910)}=18.67, \mathrm{p}<0.0001\right)$ increase of $\mathrm{Hg}$ concentration with ageing was detected when considering all individuals together, regardless of their species or origin (Fig. 6). When separating species and sites (Table 2), significant differences in Hg concentration between ages were observed for M. barbatus at Banyuls, Sète and Nice, and for M. surmuletus at La Seyne, Nice and Sant’Amanza. Concentrations were always higher for older individuals, whether differences were significant or not.

\section{Discussion}

Albeit Hg content has been largely investigated in Mediterranean red mullet (M. barbatus and M. surmuletus), few studies have compared results obtained from different areas. Similarly, seasonal variations of $\mathrm{Hg}$ concentration have rarely been investigated in marine teleosts whereas seasonal cycles can potentially affect Hg concentrations. This study has made good this lack, and identified certain features that may be the cause of the patterns observed.

\section{Inter- and intra-specific variability of $\mathrm{Hg}$ concentrations}

Mean mercury concentrations ranged between 0.23 and $0.78 \mu \mathrm{g} \mathrm{g}^{-1}$, consistently with previously reported results for mullids from the Mediterranean Sea (Table. 3). Most of the values measured were below the $2.5 \mu \mathrm{g} \mathrm{g}^{-1} \mathrm{dm}$ safety value defined by the European Commission (EC, 2006). The similar Hg burden within the two species, when individuals from Corsica are excluded, is consistent with previous results (Capelli et al. 2004; HarmelinVivien et al., 2009). At the size considered here (10 to $22 \mathrm{~cm})$, M. barbatus and M. surmuletus have a similar diet, based on small benthic invertebrates (Bautista-Vega et al., 2008; Labropoulou et al., 1997; Machias and Labropoulou, 2002). As diet is the main source of Hg contamination in fishes (Hall et al., 1997), this similar diet may explain the absence of difference in Hg concentration. The high inter-specific discrepancy observed only at Sant'Amanza, with lower values in M. barbatus, could be linked with the faster growth of M. barbatus and justifies an extensive assessment of the Corsican situation (see below). 
It is generally considered that $\mathrm{Hg}$ bioaccumulation occurs all along the fish life. In other words, larger and older fishes display higher mercury concentrations, meaning that the rate of Hg uptake in fish tissue are higher than their rate of excretion. Several biological processes have been invoked to explain this process, such as accumulation due to chronic exposure to contaminant, lower biodilution due to lower somatic growth and investment in reproduction for mature individuals or ontogenetic change of diet (Cossa et al., 2012; Harmelin-Vivien et al., 2009; Magalhães et al., 2007). Here, length was not a good descriptor of $\mathrm{Hg}$ contamination, what is comparable with the results of Harmelin-Vivien et al. (2009) who observed few correlations and only for $M$. barbatus. Age appeared to be a better descriptor of Hg bioaccumulation, as age provides absolute information about exposure time whereas length is dependent upon the life history parameter of each individual. Considering this discrepancy is crucial when comparing $\mathrm{Hg}$ concentrations of individuals living in different environments, where abiotic parameters can affect metabolism and growth. The low correlation between length and Hg concentration could be caused by the high inter-individual variability. This trend is clearly illustrated by the dispersion of the points in Figure 5. Due to individual life history, two individuals can be exposed to different Hg contamination. In addition, individuals exposed to the same $\mathrm{Hg}$ contamination may exhibit different $\mathrm{Hg}$ concentrations as they potentially have a different metabolism. This idea is also supported by the trend observed for M. barbatus at La Seyne and for M. surmuletus at Banyuls and Sant'Amanza. The largest individuals exhibited lower Hg concentrations than the smallest individuals, inconsistently with the expected bioaccumulation of Hg. It could be hypothesized that the spatial segregation between small and large individuals previously described (Machias et al., 1998; Lombarte et al., 2000) causes this unexpected trend. In those papers, authors described a migration of larger individuals towards deeper waters and the predominance of smaller individuals in shallower zones. Here, if the small individuals are living and feeding in the bay, they would be under the influence of the highly contaminated sediments of the bay of Toulon (Tessier et al., 2011). On the contrary, due to ontogenetic migration, larger individuals would live and feed outside the bay, in environments with lower Hg contamination. This result is similar with those of Greenfield et al (2013) who observed different $\mathrm{Hg}$ concentration for two fish species caught at the same site, as one is sedentary, whereas the other has an extensive range of movement. The different Hg concentration in fish reflects the exposition to different Hg sources. Further study, focused on a larger number of individuals and on a large range of sizes is required to reach a definitive conclusion on that point. It should also include complementary analyses, such as the determination of stable 
isotope ratios of $\mathrm{C}$ and $\mathrm{N}$, to verify whether or not large individuals belonged to a different trophic network, with lower Hg concentrations.

\section{Temporal variation of $\mathrm{Hg}$ concentration}

Seasonal variation of $\mathrm{Hg}$ content in marine fishes is poorly documented (Greenfield et al. 2013; Kucuksezgin et al., 2001; Mathieson et al., 1996). As Hg has a higher affinity for proteins, muscle displays a higher Hg concentration than gonads (Webb et al., 2006). Thus, Hg losses due to spawning are negligible (Trudel and Rassmussen, 2006). As a consequence, most studies documented no sex variation of $\mathrm{Hg}$ content in fishes (Harmelin-Vivien et al., 2009; Magalhães et al., 2007; Martínez-Gómez et al., 2012). The seasonal variation observed in the present study could be linked with a seasonal variation of feeding intensity, as diet is the main source of $\mathrm{Hg}$ in fishes (Hall et al., 1997) and less than $0.1 \%$ of the $\mathrm{Hg}$ results from a direct uptake of Hg from water (Trudel and Rasmussen, 2006). Higher Hg concentrations were measured between April and August, concomitantly with the reproductive season of red mullet in the Mediterranean (Machias and Labropoulou, 2002; Reñones et al., 1995; Vassilopoulou and Georgakopoulos-Gregoriades, 1993). In contrast to other fish species which store reserves prior to the reproductive season to supply reproductive needs, red mullet exhibit intensive feeding activity during the spawning season (Lloret et al., 2007). Increasing the feeding activity would consequently increase the Hg contamination at this time. In addition, a seasonal variation of Hg bioavailability was previously documented. A higher Hg concentration in summer for several benthic invertebrates such as crustaceans, annelids or mollusks was recently documented (Cardoso et al. 2014). Such invertebrates are the main prey of red mullet, so a similar trend for Mediterranean invertebrates could explain the seasonal variation observed. In addition, a decrease in Hg methylation in winter previously measured in the Mediterranean could cause the lower Hg values measured in red mullet sampled in winter (Heimbürger et al. 2010).

\section{Geographical comparison of $\mathrm{Hg}$ concentration in red mullet}

In this work, Mullus spp. individuals were sampled at five Mediterranean sites exhibiting different environmental Hg contamination. Results segregated three groups of locations depending on their Hg concentration: Banyuls and Sète with low Hg concentrations, Nice where intermediate values were measured, and finally La Seyne and Sant'Amanza where Hg concentrations were the highest. Results measured in red mullet were consistent with environmental values and contamination pressure at all sites except Sant'Amanza. 
Low Hg concentration at Sète and Banyuls are consistent with previous values obtained in the same zone in sediment, mussels (Table S1) and in the muscle of common sole Solea solea (Dierking et al., 2009). These authors explained the low values they recorded by the absence of a major Hg source in the immediate vicinity, compared to other sites in the Gulf of Lions. At Nice, the harbor is a major hotspot of $\mathrm{Hg}$ contamination in sediment but fishes were sampled away from the harbor. A weak influence of the harbor and the city may explain the intermediate Hg concentrations observed at Nice. Similarly, the high mercury concentrations measured for both species in La Seyne were consistent with previous knowledge of high $\mathrm{Hg}$ content locally measured in sediment and caged mussels (Andral et al., 2004; Tessier et al., 2011). Values in red mullet were thus representative of the environmental Hg contamination at these four sites.

The high mercury concentrations in M. surmuletus from Sant'Amanza might appear surprising. Corsica is commonly considered as a weakly impacted zone, subjected to limited anthropogenic pressures. Several early papers compared Hg concentration in sediment, mussels or the seagrass Posidonia oceanica and observed lower mercury concentrations in Corsica than in other parts of the Western Mediterranean (Andral et al., 2004; Galgani et al., 2006; Lafabrie et al., 2007; Pergent-Martini, 1998; Pergent et al., 2011; Serrano et al., 2013). The oligotrophy of Corsican waters (in comparison with the waters of the Gulf of Lions and Provence area, Bosc et al., 2004) may be a major factor causing the discrepancy between low environmental Hg concentrations and high concentrations in red mullet.

First, phytoplanktonic communities in Corsica are dominated by nano- and picophytoplankton, just as in all oligotrophic zones (Garrido et al., 2014). Heimbürger et al. (2010) showed that Hg methylation is enhanced in the presence of nano- and picophytoplankton. Thus, a higher amount of organic mercury is available for bioamplification in oligotrophic zones. In addition, due to the lower amount of biogenic particles, mercury is less bio-diluted by biogenic particles and is more easily integrated at the basis of trophic networks (Cossa et al., 2012). Higher methylation and lower biodilution at the base of the trophic network were proposed as explanations of the different $\mathrm{Hg}$ concentrations in red mullet sampled in the Gulf of Lions and in the Black Sea. M. barbatus ponticus, sampled in the eutrophic Black Sea, exhibit markedly lower Hg concentrations than M. barbatus barbatus and M. surmuletus in the mesotrophic Gulf of Lions, whereas Hg concentrations in water are similar in the two geographic zones and these fish occupy the same trophic position (Harmelin-Vivien et al., 2009). Whilst Mullus spp. are benthic burrowing feeders, the latter 
and other recent results based on carbon and nitrogen stable isotopes ratios demonstrated that the trophic network they belong to is dependent upon the falling pelagic primary production (Cresson et al., 2014 a,b). If Hg is less biodiluted, integration of this matter in the trophic network would result in a higher Hg contamination. Secondly, due to the lower amount of particles, the growth of organisms could be slower in oligotrophic zones. With regard to contamination, a slow-growing organism synthesizes less tissue than a fast-growing one and bio-dilutes less the Hg contamination in tissues. Slow growing organisms thus display a higher Hg content. Oligotrophy explained the lower condition indices and Hg burden measured for caged mussels deployed in Corsica (Andral et al., 2004) and also the lower growth rate and the higher $\mathrm{Hg}$ for hake Merluccius merluccius sampled in the Gulf of Lions, in comparison with fish sampled in the eutrophic Bay of Biscay in the Atlantic (Cossa et al. 2012). Here it could be the cause of the lower Hg values in fast growing M. barbatus individuals (Fig. S1).

It is of interest to note that several authors also observed a discrepancy between environmental values and Mullus spp. body burden (Martínez Gómez et al., 2012; Storelli and Marcotrigiano, 2005). Authors attributed this discrepancy to the input of $\mathrm{Hg}$ from distant zones (Storelli and Marcotrigiano, 2005) or to a dietary switch and the consumption of more contaminated prey for individuals displaying high Hg concentration (Martínez-Gómez et al., 2012). Even if these hypotheses should not be rejected per se, no consideration was given to biological and abiotic factors. As demonstrated earlier, oligotrophy can increase the amount of $\mathrm{Hg}$ available for bio-accumulation in the trophic networks. In addition, previous results demonstrated that, under eutrophic conditions, fish grow faster and dilute more $\mathrm{Hg}$ contamination in newly synthesized tissues, resulting in a lower Hg concentration in fastergrowing fishes (Cossa et al., 2012). In the work of Martínez-Gómez et al (2012), lipid content and condition factor (ratio between eviscerated mass and cubic length) were presented. Fishes sampled at the site with higher Hg concentrations in sediment exhibited higher lipid content and condition factors. Thus, the faster growth of these fishes may have diluted their $\mathrm{Hg}$ burden and this might explain the lower and unexpected Hg concentrations at a more contaminated site. Considering the abiotic features of the environment and the resulting biological status of the organisms is thus crucial to correctly interpret contamination patterns.

\section{Conclusions}


The results obtained here confirmed that Mullus spp. caught along the French Mediterranean coast are efficient bio-indicators of mercury contamination. This is not surprising as those species have been identified as such and already used in several studies. The geographical trend observed is consistent with knowledge regarding different levels of chemical contamination, mainly at La Seyne on the one hand and at Sète and Banyuls on the other hand. In addition, as M. barbatus and M. surmuletus are widely consumed, it is crucial to assess their Hg contamination, to detect and prevent possible human contamination while consuming these fishes. The quite low average values, comprised between $0.23 \pm 0.19$ and $0.78 \pm 0.36 \mu \mathrm{g} \mathrm{g}^{-1} \mathrm{dm}$, make this rather unlikely, even if several high values were observed. Nevertheless, observations from Corsica coasts underline again that caution must be taken when bio-indicators are used to infer environmental contaminant impregnation. Biological factors of the bio-indicator species and specificities of the studied zone must be kept in mind to interpret $\mathrm{Hg}$ concentrations in biota. The high inter-individual variability of $\mathrm{Hg}$ concentrations, potentially linked with individual life history and metabolism, calls for extensive sampling. Seasonal variation should also be considered, as the annual cycle of the species could impact Hg content. Finally, the Corsican case also calls for caution, as the level of productivity and fish growth could blur the data. Raw values observed in biota are not always a direct indicator of environmental Hg concentrations. A good knowledge of these biological processes (e.g. diet or growth) and of the abiotic parameters they are ruled by (e.g. temperature or productivity of the zone etc.) is required for an accurate interpretation of $\mathrm{Hg}$ concentrations, and for the comparison of contamination between studies investigating different zones.

\section{Acknowledgements}

Thanks are due to the fishermen (Frederic Le Guen, Philippe Mazel and Julien Grodeau) and to our colleagues (Yves Dimeglio, IRSN La Seyne sur Mer, Yoan Baldi, Ifremer, LER/PAC, Bastia and Jean Michel Cottalorda, ECOMERS, Nice University) who caught and processed the fishes. Special thanks to F. Le Guen who kindly provided information on his fishing practices and observations about red mullet. We would also like to thank Jean-François Chiffoleau (Ifremer, LBCM Nantes) for data on Hg concentration in sediment and Maryvonne Henry (Ifremer LER/PAC, La Seyne sur Mer) for drawing the map Figure 1. We thank Michael Paul, native English speaker, for improvement of the English of previous versions of 
the manuscript and to an anonymous reviewer for constructive comments on a previous version of the manuscript. This study is part of the RETROMED program, funded by grants n² 2013-0647 from Agence de l’Eau Rhone Méditerranée Corse, and of the radiological monitoring program of the IRSN

\section{Bibliographical references}

Andral, B., Stanisiere, J.Y., Sauzade, D., Damier, E., Thebault, H., Galgani, F., Boissery, P., 2004. Monitoring chemical contamination levels in the Mediterranean based on the use of mussel caging. Marine Pollution Bulletin 49, 704-712.

Bautista-Vega, A.A., Letourneur, Y., Harmelin-Vivien, M., Salen-Picard, C., 2008.

Difference in diet and size-related trophic level in two sympatric fish species, the red mullets Mullus barbatus and Mullus surmuletus, in the Gulf of Lions (north-west Mediterranean Sea). Journal of Fish Biology 73, 2402-2420.

Beyer, J., Sandvik, M., Hylland, K., Fjeld, E., Egaas, E., Aas, E., Skåre, J.U., Goksøyr, A., 1996. Contaminant accumulation and biomarker responses in flounder (Platichthys flesus L.) and Atlantic cod (Gadus morhua L.) exposed by caging to polluted sediments in Sørfjorden, Norway. Aquatic Toxicology 36, 75-98.

Blum, J.D., Popp, B.N., Drazen, J.C., Choy, C.A., Johnson, M.W., 2013. Methylmercury production below the mixed layer in the North Pacific Ocean. Nature Geoscience 6, 879-884.

Bosc, E., Bricaud, A., Antoine, D., 2004. Seasonal and interannual variability in algal biomass and primary production in the Mediterranean Sea, as derived from 4 years of SeaWiFS observations. Global Biogeochemical Cycles 18, GB1005.

Capelli, R., Drava, G., Siccardi, C., De Pellegrini, R., Minganti, R. 2004. Study of the distibution of trace elements in marine organisms of the Ligurian Sea (North-Western Mediterranean) - Comparison with previous findings. Annali di Chimica 94, 533-546

Cardoso, P.,G., Pereira, E., Duarte,A.,C., Azeiteiro, U.,M. 2014. Temporal characterization of mercury accumulation at different trophic levels and implications for metal biomagnification along a coastal food web. Marine Pollution Bulletin. 87, 39-47

Conti, G.O., Copat, C., Ledda, C., Fiore, M., Fallico, R., Sciacca, S., Ferrante, M., 2012. Evaluation of heavy metals and polycyclic aromatic hydrocarbons (PAHs) in Mullus barbatus 
from Sicily Channel and risk-based consumption limits. Bulletin of environmental contamination and toxicology 88, 946-950.

Company R, Felícia H, Serafim A, Almeida AJ, Biscoito M, Bebianno MJ. Metal concentrations and metallothionein-like protein levels in deep-sea fishes captured near hydrothermal vents in the Mid-Atlantic Ridge off Azores. Deep-Sea Res Part I 2010;57: 893908.

Copat, C., Bella, F., Castaing, M., Fallico, R., Sciacca, S., Ferrante, M., 2012. Heavy metals concentrations in fish from Sicily (Mediterranean Sea) and evaluation of possible health risks to consumers. Bulletin of environmental contamination and toxicology 88, 78-83.

Corsi, I., Mariottini, M., Menchi, V., Sensini, C., Balocchi, C., Focardi, S., 2002. Monitoring a marine coastal area: use of Mytilus galloprovincialis and Mullus barbatus as bioindicators. Marine Ecology 23, 138-153.

Cossa, D., Averty, B., Pirrone, N., 2009. The origin of methylmercury in open Mediterranean waters. Limnology and Oceanography 54, 837-844.

Cossa, D., Harmelin-Vivien, M., Mellon-Duval, C., Loizeau, V., Averty, B., Crochet, S., Chou, L., Cadiou, J.F., 2012. Influence of bioavailability, trophic position, and growth on methylmercury in hakes (Merluccius merluccius) from Northwestern Mediterranean and Northeast Atlantic. Environmental Science and Technology 46, 4885-4893.

Cresson, P., Ruitton, S., Harmelin-Vivien, M., 2014a. Artificial reefs do increase secondary biomass production: mechanisms evidenced by stable isotopes. Marine Ecology Progress Series. 509: 15-26

Cresson, P., Ruitton, S., Ourgaud, M., Harmelin-Vivien, M., 2014b. Contrasting perception of fish trophic level from stomach content and stable isotope analyses: A Mediterranean artificial reef experience. Journal of Experimental Marine Biology and Ecology 452, 54-62.

Dierking, J., Wafo, E., Schembri, T., Lagadec, V., Nicolas, C., Letourneur, Y., HarmelinVivien, M., 2009. Spatial patterns in PCBs, pesticides, mercury and cadmium in the common sole in the NW Mediterranean, and a novel use of contaminants as a biomarker. Marine Pollution Bulletin 58, 1605-1614.

Durrieu de Madron, X., Guieu, C., Sempéré, R., Conan, P., Cossa, D., D’Ortenzio, F., Estournel, C., Gazeau, F., Rabouille, C., Stemmann, L., et al., 2011. Marine ecosystems’ 
responses to climatic and anthropogenic forcings in the Mediterranean. Progress in Oceanography 91, 97-166.

EC, 2006. Commision regulation (EC) No 1881/2006 of 19 December 2006 setting maximum levels for certain contaminants in foodstuffs (Text with EEA relevance).

Endo, T., Hayasaka, M., Hisamichi, Y., Kimura, O., Haraguchi, K., 2013. Carbon and nitrogen stable isotope ratios and mercury concentration in the scalp hair of residents from Taiji, a whaling town. Marine Pollution Bulletin 69, 116-121.

Falcó, G., Llobet, J.M., Bocio, A., Domingo, J.L., 2006. Daily intake of arsenic, cadmium, mercury, and lead by consumption of edible marine species. Journal of agricultural and food chemistry 54, 6106-6112.

FAO, 2012. The state of world fisheries and aquaculture 2012, Rome.

Filipović, V., Raspor, B. 2003. Metallothionein and metal levels in cytosol of liver, kidney and brain in relation to growth parameters of Mullus surmuletus and Liza aurata from the Eastern Adriatic Sea. Water research, 37, 3253-3262.

Fleeger, J.W., Carman, K.R., Nisbet, R.M., 2003. Indirect effects of contaminants in aquatic ecosystems. Science of The Total Environment 317, 207-233.

Galgani, F., Chiffoleau, J.-F., Orsoni, V., Costantini, L., Boissery, P., Calendini, S., Andral, B., 2006. Chemical contamination and sediment toxicity along the coast of Corsica.

Chemistry and Ecology 22, 299-312.

Garrido, M., Koeck, B., Goffart, A., Collignon, A., Hecq, J.-H., Agostini, S., Marchand, B., Lejeune, P., Pasqualini, V., 2014. Contrasting Patterns of Phytoplankton Assemblages in Two Coastal Ecosystems in Relation to Environmental Factors (Corsica, NW Mediterranean Sea). Diversity 6, 296-322.

Greenfield, B.K., Melwani, A.R., Allen, R.M., Slotton, D.G., Ayers, S.M., Harrold, K.H., Ridolfi, K., Jahn, A., Grenier, J.L., Sandheinrich, M.B., 2013. Seasonal and annual trends in forage fish mercury concentrations, San Francisco Bay. Science of The Total Environment 444, 591-601.

Hall, B.D., Bodaly, R.A., Fudge, R.J.P., Rudd, J.W.M., Rosenberg, D.M., 1997. Food as the Dominant Pathway of Methylmercury Uptake by Fish. Water, Air, and Soil Pollution 100, 1324. 
Halpern, B.S., Walbridge, S., Selkoe, K.A., Kappel, C.V., Micheli, F., D'Agrosa, C., Bruno, J.F., Casey, K.S., Ebert, C., Fox, H.E., et al., 2008. A Global Map of Human Impact on Marine Ecosystems. Science 319, 948-952.

Harmelin-Vivien, M., Cossa, D., Crochet, S., Bănaru, D., Letourneur, Y., Mellon-Duval, C., 2009. Difference of mercury bioaccumulation in red mullets from the north-western Mediterranean and Black seas. Marine Pollution Bulletin 58, 679-685.

Heimbürger, L.E., Cossa, D., Marty, J.C., Migon, C., Averty, B., Dufour, A., Ras, J., 2010. Methyl mercury distribution in relation to the presence of nano- and picophytoplankton in an oceanic water column (Ligurian Sea, North-western Mediterranean). Geochemica et Cosmochimica Acta 74, 5549-5559.

Hernández-Hernández, F., Medina, J., Ansuátegui, J., Conesa, M. 1990. Heavy metal concentrations in some marine organisms from the Mediterranean Sea (Castellon, Spain): Metal accumulation in different tissues. Scientia Marina 54, 113-129.

ICES, 2012. Report of the workshop on age reading of red mullet and striped red mullet (WKACM2), 2-6 July 2012, Boulogne sur-Mer, France. ICES CM 2012/ACOM: 60, pp. 52.

Kucuksezgin, F., Altay, O., Uluturhan, E., Kontas, A., 2001. Trace Metal and Organochlorine Residue Levels in Red Mullet (Mullus barbatus) from the Eastern Aegean, Turkey. Water Research 35, 2327-2332.

Kucuksezgin, F., Kontas, A., Uluturhan, E., 2011. Evaluations of heavy metal pollution in sediment and Mullus barbatus from the Izmir Bay (Eastern Aegean) during 1997-2009. Marine Pollution Bulletin 62, 1562-1571.

Labropoulou, M., Machias, A., Tsimenides, N., Eleftheriou, A., 1997. Feeding habits and ontogenetic diet shift of the striped red mullet, Mullus surmuletus Linnaeus, 1758 Fisheries Research 31, 257-267.

Lafabrie, C., Pergent, G., Kantin, R., Pergent-Martini, C., Gonzalez, J.-L., 2007. Trace metals assessment in water, sediment, mussel and seagrass species-Validation of the use of Posidonia oceanica as a metal biomonitor. Chemosphere 68, 2033-2039.

Leleu, K., Pelletier, D., Charbonnel, E., Letourneur, Y., Alban, F., Bachet, F., Boudouresque, C.F., 2014. Métiers, effort and catches of a Mediterranean small-scale coastal fishery: The case of the Côte Bleue Marine Park. Fisheries Research 154, 93-101. 
Lloret, J., Demestre, M., Sánchez-Pardo, J., 2007. Lipid reserves of red mullet (Mullus barbatus) during pre-spawning in the northwestern Mediterranean. Scientia Marina 71, 269277.

Lombarte, A., Recasens, L., González, M., de Sola, L.G., 2000. Spatial segregation of two species of Mullidae (Mullus surmuletus and M. barbatus) in relation to habitat. Marine Ecology Progress Series 206, 239-249.

Machias, A., Labropoulou, M., 2002. Intra-specific Variation in Resource Use by Red Mullet, Mullus barbatus. Estuarine, Coastal and Shelf Science 55, 565-578.

Machias, A., Somarakis, S., Tsimenides, N. 1998. Bathymetric distribution and movements of red mullet Mullus surmuletus. Marine Ecology Progress Series 166, 247-257

Magalhães, M.C., Costa, V., Menezes, G.M., Pinho, M.R., Santos, R.S., Monteiro, L.R., 2007. Intra- and inter-specific variability in total and methylmercury bioaccumulation by eight marine fish species from the Azores. Marine Pollution Bulletin 54, 1654-1662.

Mahé, K., Coppin, F., Vaz, S., Carpentier, A., 2013. Striped red mullet (Mullus surmuletus, Linnaeus, 1758) in the eastern English Channel and southern North Sea: growth and reproductive biology. Journal of Applied Ichthyology 29, 1067-1072.

Martí-Cid, R., Bocio, A., Llobet, J.M., Domingo, J.L., 2007. Intake of chemical contaminants through fish and seafood consumption by children of Catalonia, Spain: Health risks. Food and Chemical Toxicology 45, 1968-1974.

Martínez-Gómez, C., Fernández, B., Benedicto, J., Valdés, J., Campillo, J.A., León, V.M., Vethaak, A.D., 2012. Health status of red mullets from polluted areas of the Spanish Mediterranean coast, with special reference to Portmán (SE Spain). Marine Environmental Research 77, 50-59.

Mathieson, S., George, S., McLusky, D., 1996. Temporal variation of total mercury concentrations and burdens in the liver of eelpout Zoarces viviparus from the Forth Estuary, Scotland: Implications for mercury biomonitoring. Marine Ecology Progress Series 138, 4149.

Mieiro, C. L., Bervoets, L., Joosen, S., Blust, R., Duarte, A. C., Pereira, M. E., Pacheco, M. (2011). Metallothioneins failed to reflect mercury external levels of exposure and bioaccumulation in marine fish-Considerations on tissue and species specific responses. Chemosphere, 85, 114-121. 
Morat, F., Letourneur, Y., Nerini, D., Banaru, D., Batjakas, I.E., 2012. Discrimination of red mullet populations (Teleostean, Mullidae) along multi-spatial and ontogenetic scales within the Mediterranean basin on the basis of otolith shape analysis. Aquatic Living Resources 25, 27-39.

Nakhlé, K., Cossa, D., Claisse, D., Beliaeff, B., Simon, S., 2007. Cadmium and mercury in Seine Estuary flounders and muscle: the results of two decades of monitoring. ICES Journal of Marine Science 64, 929-938.

Pergent-Martini, C., 1998. Posidonia oceanica: a biological indicator of past and present mercury contamination in the Mediterranean sea. Marine Environmental Research 45, 101111.

Pergent, G., Labbe, C., Lafabrie, C., Kantin, R., Pergent-Martini, C., 2011. Organic and inorganic human-induced contamination of Posidonia oceanica meadows. Ecological Engineering 37, 999-1002.

Perugini, M., Visciano, P., Manera, M., Zaccaroni, A., Olivieri, V., Amorena, M., 2009. Levels of total mercury in marine organisms from Adriatic Sea, Italy. Bulletin of environmental contamination and toxicology 83, 244-248.

Phillips, D.J., Rainbow, P.S., 1998. Biomonitoring of trace aquatic contaminants. Springer. R Core Team, 2014. R: A langage and environment for statistical computing. R foundation for Statistical computing, Vienna, Austria.

Reñones, O., Massuti, E., Morales-Nin, B., 1995. Life history of the red mullet Mullus surmuletus from the bottom-trawl fishery off the Island of Majorca (north-west Mediterranean). Marine Biology 123, 411-419.

Scheuhammer, A.M., Meyer, M.W., Sandheinrich, M.B., Murray, M.W., 2007. Effects of Environmental Methylmercury on the Health of Wild Birds, Mammals, and Fish. AMBIO: A Journal of the Human Environment 36, 12-19.

Serrano, O., Martínez-Cortizas, A., Mateo, M.A., Biester, H., Bindler, R., 2013. Millennial scale impact on the marine biogeochemical cycle of mercury from early mining on the Iberian Peninsula. Global Biogeochemical Cycles 27, 21-30.

Storelli, M.M., Marcotrigiano, G.O., 2005. Bioindicator organisms: Heavy metal pollution evaluation in the Ionian Sea (Mediterranean Sea - Italy). Environmental Monitoring and Assesment 102, 159-166. 
Storelli, M.M., Storelli, A., Giacominelli-Stuffler, R., Marcotrigiano, G.O., 2005. Mercury speciation in the muscle of two commercially important fish, hake (Merluccius merluccius) and striped mullet (Mullus barbatus) from the Mediterranean sea: estimated weekly intake. Food Chemistry 89, 295-300.

Streets, D., Devane, M., Lu, Z., Bond, T., Sunderland, E., Jacob, D., 2011. All-Time Releases of Mercury to the Atmosphere from Human Activities. Environmental Science and Technology 45, 10485 - 10491.

Tartu, S., Goutte, A., Bustamante, P., Angelier, F., Moe, B., Clément-Chastel, C., Bech, C., Gabrielsen, G.W., Bustnes, J.O., Chastel, O., 2013. To breed or not to breed: endocrine response to mercury contamination by an Arctic seabird. Biology Letters 9, 20130317.

Tessier, E., Garnier, C., Mullot, J.-U., Lenoble, V., Arnaud, M., Raynaud, M., Mounier, S., 2011. Study of the spatial and historical distribution of sediment inorganic contamination in the Toulon bay (France). Marine Pollution Bulletin 62, 2075-2086.

Tipton, J.A., 2008. Aristotle's observations of the foraging interactions of the red mullet (Mullidae: Mullus spp) and sea bream (Sparidae: Diplodus spp). Archives of natural history 35.

Tolga Gonul, L., Kucuksezgin, F., 2007. Mercury accumulation and speciation in the muscle of red mullet (Mullus barbatus) and annular sea bream (Diplodus annularis) from Izmir Bay (Eastern Aegean). Marine Pollution Bulletin 54, 1962-1968.

Trudel, M., Rasmussen, J., B. 2006. Bioenergetics and mercury dynamics in fish: a modelling perspective. Canadian Journal of Fisheries and Aquatic Science 63, 1890-1902

Tserpes, G., Fiorentino, F., Levi, D., Cau, A., Murenu, M., Zamboni, A., Papaconstantinou, C., 2002. Distribution of Mullus barbatus and M. surmuletus (Osteichthyes: Perciformes) in the Mediterranean continental shelf: implications for management. Scientia Marina 66, 39-54. UNEP/RAMOGE, 1999. Manual on the biomarkers reccomanded for the MED POL biomonitoring programme. UNEP, Athens.

http://195.97.36.231/acrobatfiles/MAPDocAcrobatfiles/Ramoge/Ramoge_english.pdf Vassilopoulou, V., Georgakopoulos-Gregoriades, E., 1993. Factors influencing the uptake of PCBs and DDTs in red mullet (Mullus barbatus) from Pagassitikos Gulf, central Greece. Marine Pollution Bulletin 26, 285-287. 
Webb, M. A. H., Feist, G. W., Fitzpatrick, M. S., Foster, E. P., Schreck, C. B., Plumlee, M., Wong, C., Gundersen, D. T. (2006). Mercury concentrations in gonad, liver, and muscle of white sturgeon Acipenser transmontanus in the lower Columbia River. Archives of Environmental Contamination and Toxicology, 50, 443-451.

Zorita, I., Ortiz-Zarragoitia, M., Apraiz, I., Cancio, I., Orbea, A., Soto, M., Cajaraville, M. P. (2008). Assessment of biological effects of environmental pollution along the NW Mediterranean Sea using red mullets as sentinel organisms. Environmental Pollution 153, 157-168. 


\section{Figures}

Fig. 1: Map of the sampling sites.

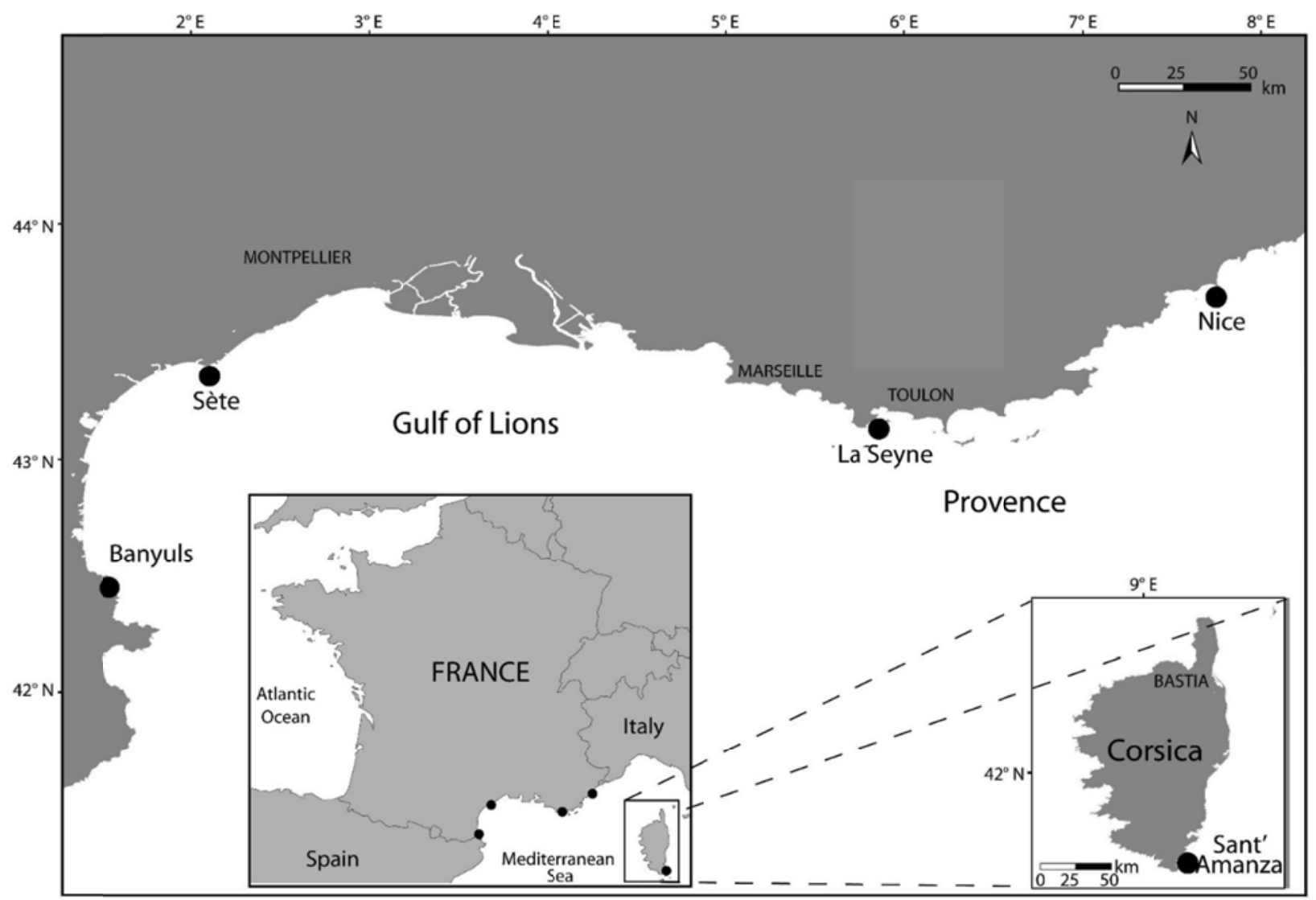


Fig. 2: Boxplots of Hg concentration ( $\mu \mathrm{g} \mathrm{g}^{-1} \mathrm{dm}$ ). Box hinges are the $1^{\text {st }}$ and $3^{\text {rd }}$ quartiles, line is the median value, whisker extends from the hinge to the highest or lowest value that is within $1.5 \mathrm{x}$ interquartile range. Points are outlier values. Horizontal hatched lines represent the maximum levels in food stuffs established by European Commission (EC, 2006) at $2.5 \mu \mathrm{g} \mathrm{g}^{-1} \mathrm{dm}$. Numbers below each site are the mean \pm sd values. n: number of individuals. LS: La Seyne, SA: Sant'Amanza
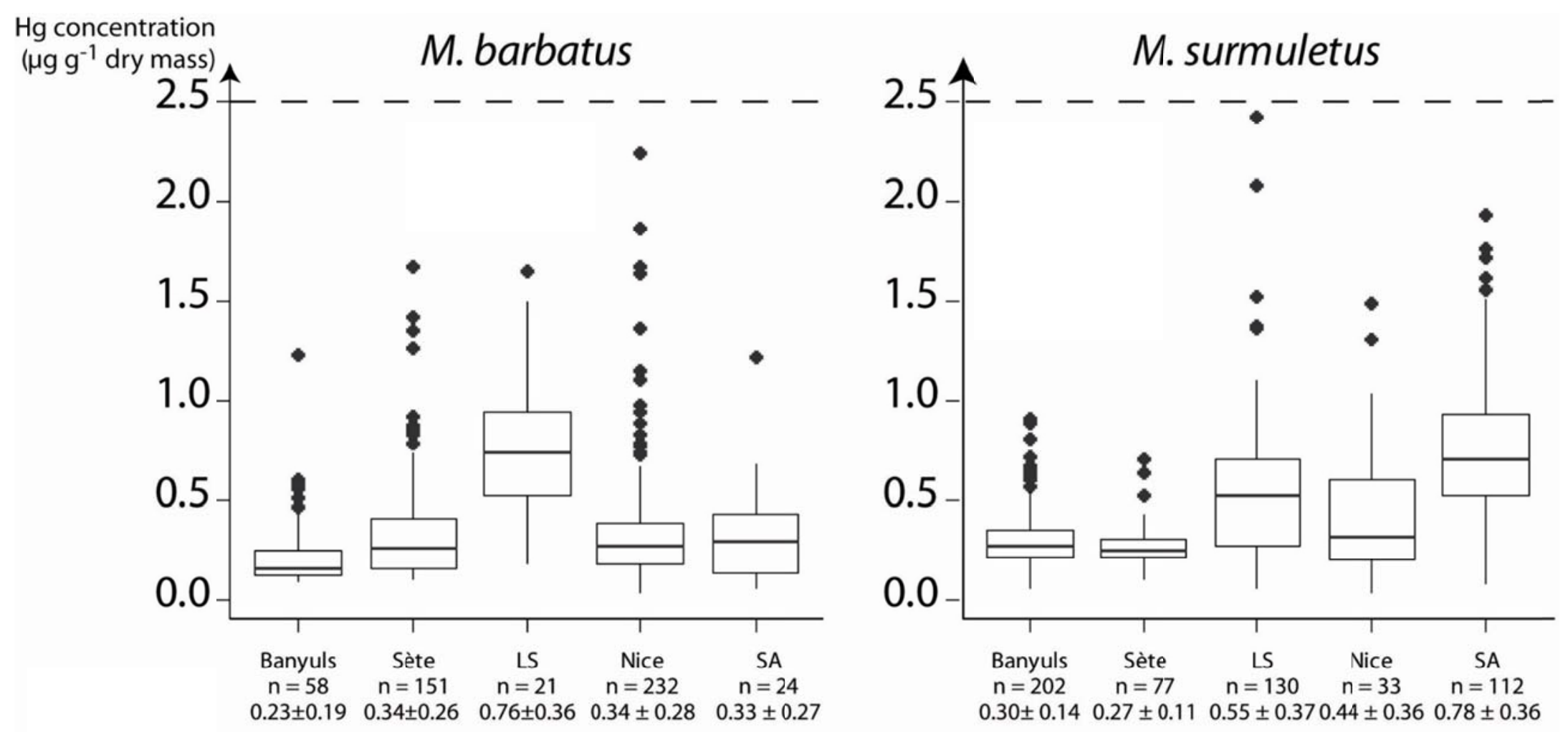
Fig. 3: Temporal variation of mean Hg concentration in each site. Months are represented by their first letter (J: June; Ap: April; Au: August).

Box hinges are the $1^{\text {st }}$ and $3^{\text {rd }}$ quartiles, line is the median value, whiskers extend from the hinge to the highest or lowest value that is within $1.5 \mathrm{x}$ interquartile range. Points are outlier values.

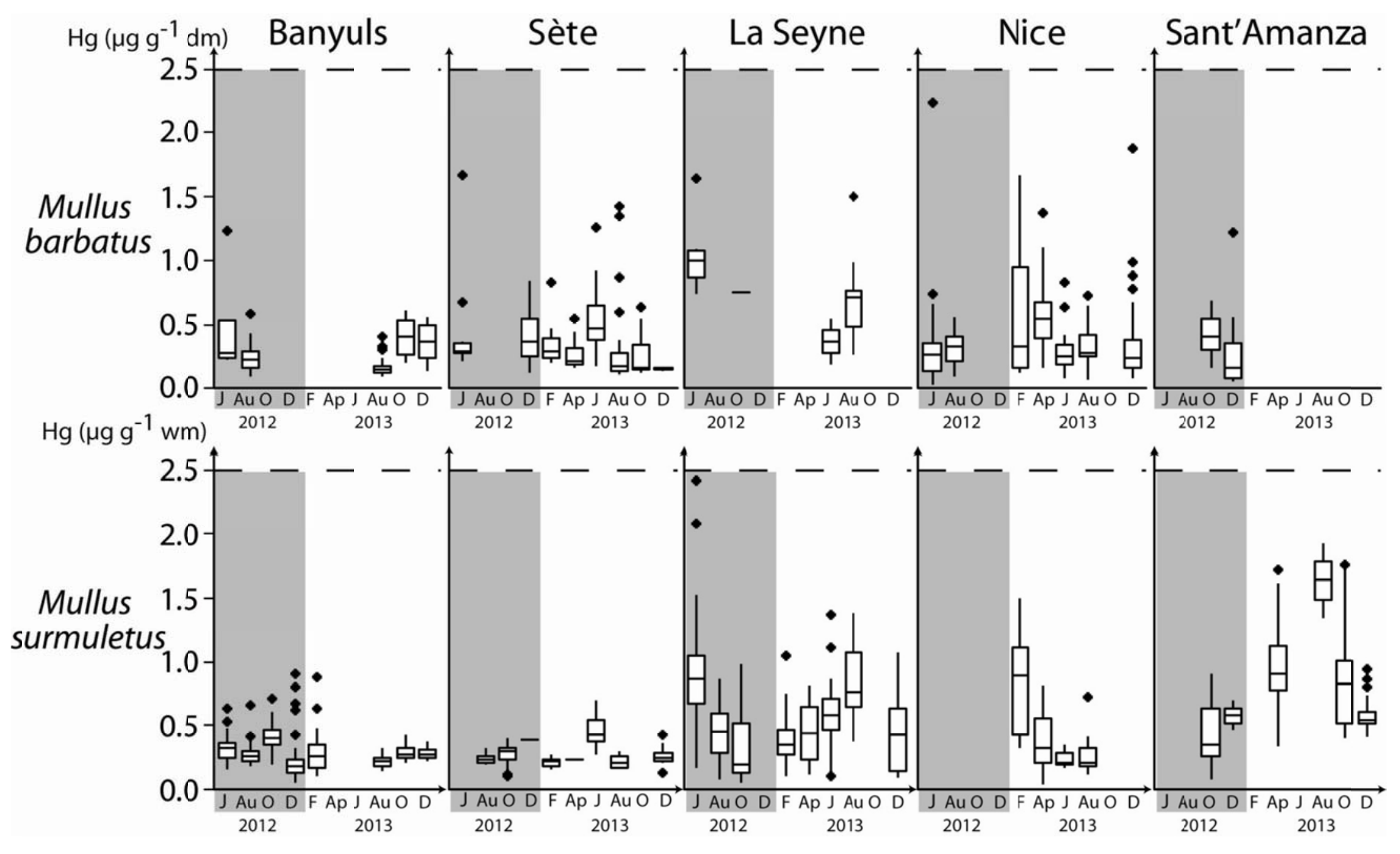


Fig. 4: Linear correlations between length (in $\mathrm{cm}$ ) and $\mathrm{Hg}$ concentration $\left(\mu \mathrm{g} \mathrm{g}^{-1} \mathrm{dm}\right)$. *** $\mathrm{p}$-value $<0.001$; $^{* *} \mathrm{p}$-value $<0.01, *$ : p-value $<0.05$, NS, non-significant, p-value $\geq 0.05$

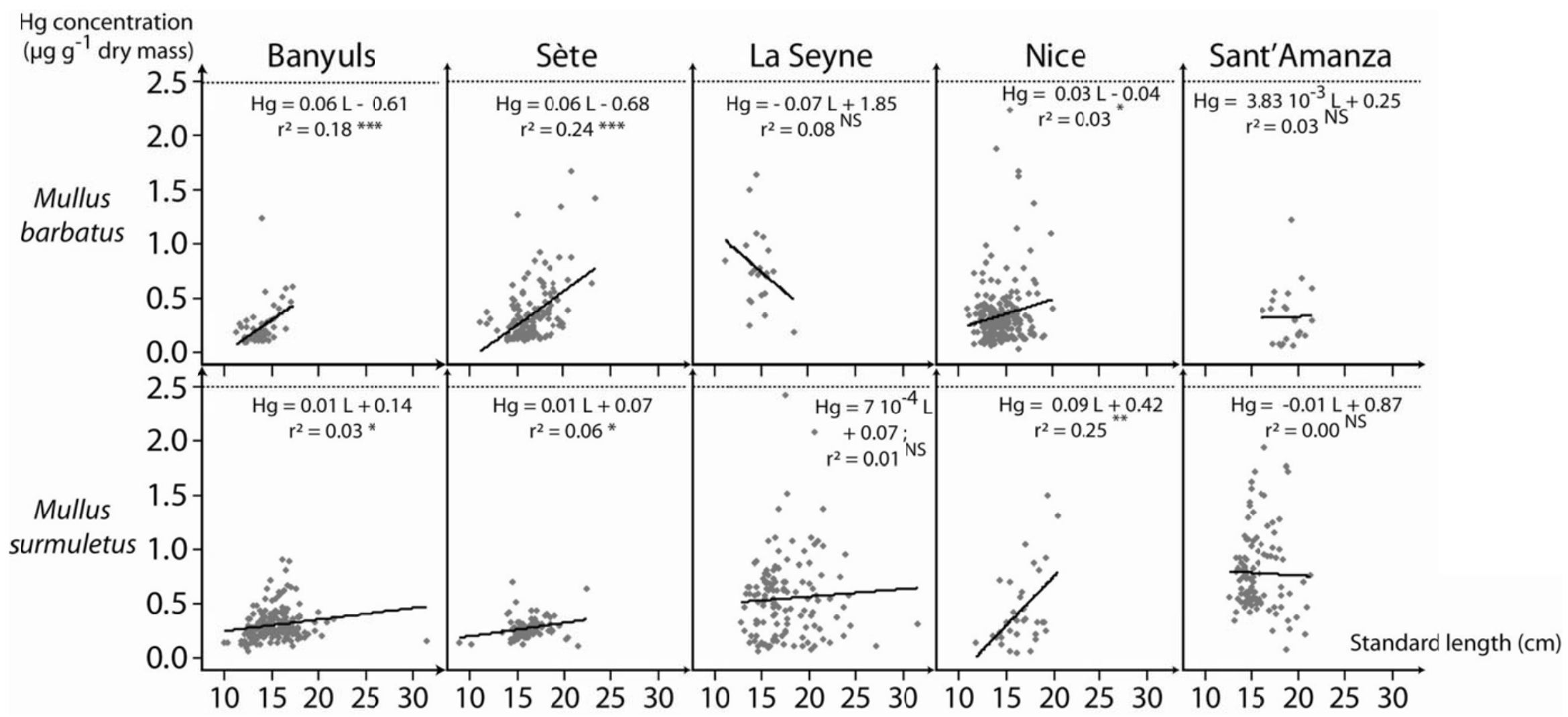


Fig. 5: Increase of the mean Hg concentration $\left(\mu \mathrm{g} \mathrm{g}^{-1}, \mathrm{dm}\right)$ with increasing age in both species and all sites. Ages with similar letter have similar $\mathrm{Hg}$ concentration. Individuals aged 0 and 4 were not included in the analysis.

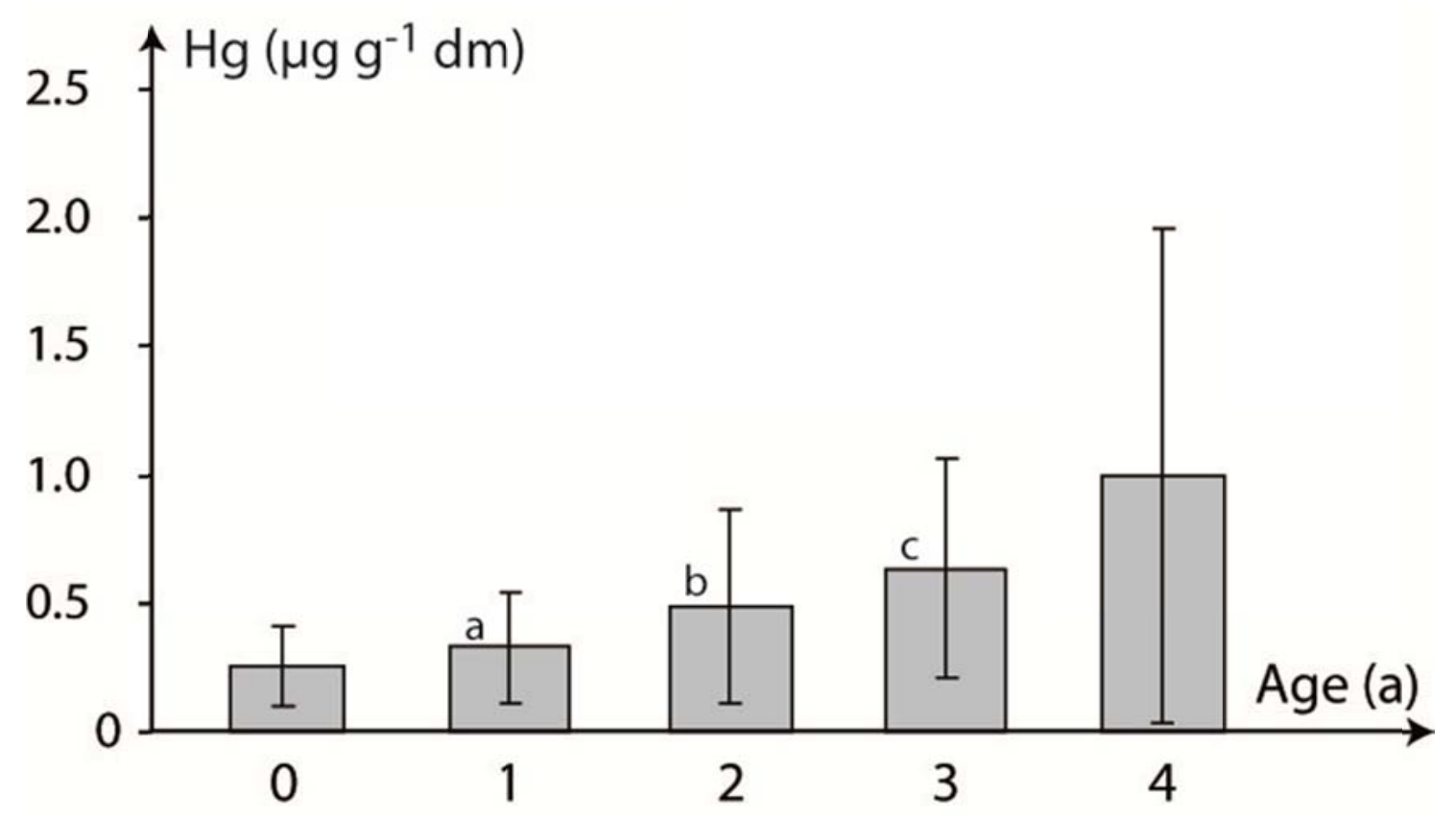


Table 1: Actual number of individuals sampled by species, sites and age classes. nd: individuals whose age was not determined

\begin{tabular}{|c|c|c|c|c|c|c|c|c|}
\hline \multirow{2}{*}{ Species } & \multirow{2}{*}{ Sites } & \multicolumn{7}{|c|}{ Ages (a) } \\
\hline & & 0 & 1 & 2 & 3 & 4 & nd & Total \\
\hline \multirow{5}{*}{ M. barbatus } & Banyuls & 3 & 39 & 9 & 1 & & 6 & 58 \\
\hline & Sète & & 63 & 52 & 25 & 1 & 10 & 151 \\
\hline & La Seyne & & 2 & 6 & & & 13 & 21 \\
\hline & Nice & 6 & 132 & 66 & 2 & 26 & & 232 \\
\hline & Sant’Amanza & & 9 & 12 & 3 & & & 24 \\
\hline \multirow{5}{*}{ M. surmuletus } & Banyuls & 10 & 118 & 53 & 2 & & 19 & 202 \\
\hline & Sète & 1 & 37 & 24 & 3 & & 12 & 77 \\
\hline & La Seyne & 2 & 34 & 43 & 21 & 1 & 31 & 132 \\
\hline & Nice & & 6 & 19 & 6 & & 2 & 33 \\
\hline & Sant'Amanza & & 56 & 44 & 6 & & 6 & 112 \\
\hline
\end{tabular}


Table 2: Comparison of mean Hg concentration by age at all sites. Comparison were performed by ANOVAs, on log-transformed Hg concentration, with length as a covariate. Individuals aged 0 and 4 years were present in low number and were not included. In the post hoc column, numbers refers to the age classes compared

\begin{tabular}{lllll}
\hline Species & Site & Stats & P value & Post Hoc (age) \\
\hline M. barbatus & Banyuls & $\mathrm{F}_{(2,46)}=5.85$ & 0.004 & $1<2<3$ \\
Sète & $\mathrm{F}_{(2,137)}=32.60$ & $<0.0001$ & $1<2<3$ \\
La Seyne & $\mathrm{F}_{(1,6)}=0.19$ & 0.67 & \\
Nice & $\mathrm{F}_{(2,197)}=8.94$ & $<0.0001$ & $1<2<3$ \\
Sant'Amanza & $\mathrm{F}_{(2,21)}=1.68$ & 0.21 & \\
M. surmuletus & & & \\
& Banyuls & $\mathrm{F}_{(2,170)}=1.29$ & 0.30 & \\
Sète & $\mathrm{F}_{(2,61)}=0.56$ & 0.57 & \\
La Seyne & $\mathrm{F}_{(2,95)}=4.81$ & 0.010 & $1<2=3$ \\
Nice & $\mathrm{F}_{(2,28)}=3.23$ & 0.004 & $1<2<3$ \\
& Sant'Amanza & $\mathrm{F}_{(2,103)}=9.09$ & $<0.0001$ & $1<3=2$ \\
\hline
\end{tabular}


Table 3: Mean Hg concentrations recorded for M. barbatus or M. sumuletus in bibliographical references in the Mediterranean Sea. When available, sampling size (n) and length parameters (mean, standard deviation, minimal and maximal lengths) were collected from the paper. If needed, wet mass was converted to dry mass using the equation dry mass $=5$ wet mass. na: data not available in the paper

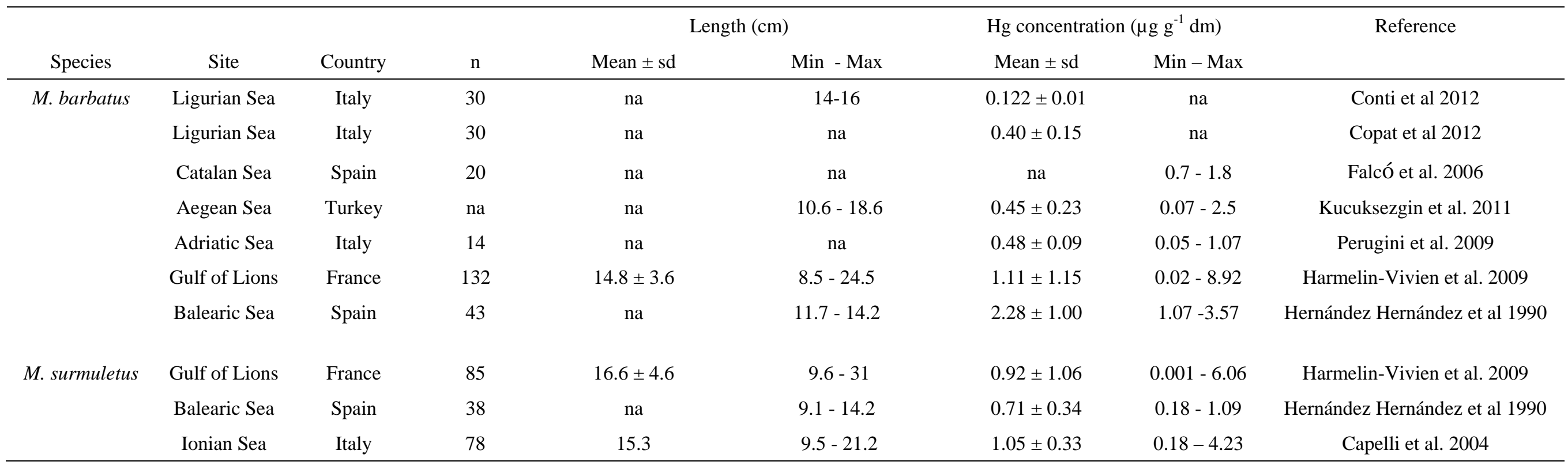




\section{Supplementary material}

Fig. S1: Comparison of fish standard lengths for each age class (in years) and in each site. Box hinges are the $1^{\text {st }}$ and $3^{\text {rd }}$ quartiles, line is the median value, whiskers extend from the hinge to the highest or lowest value that is within $1.5 \mathrm{x}$ interquartile range.
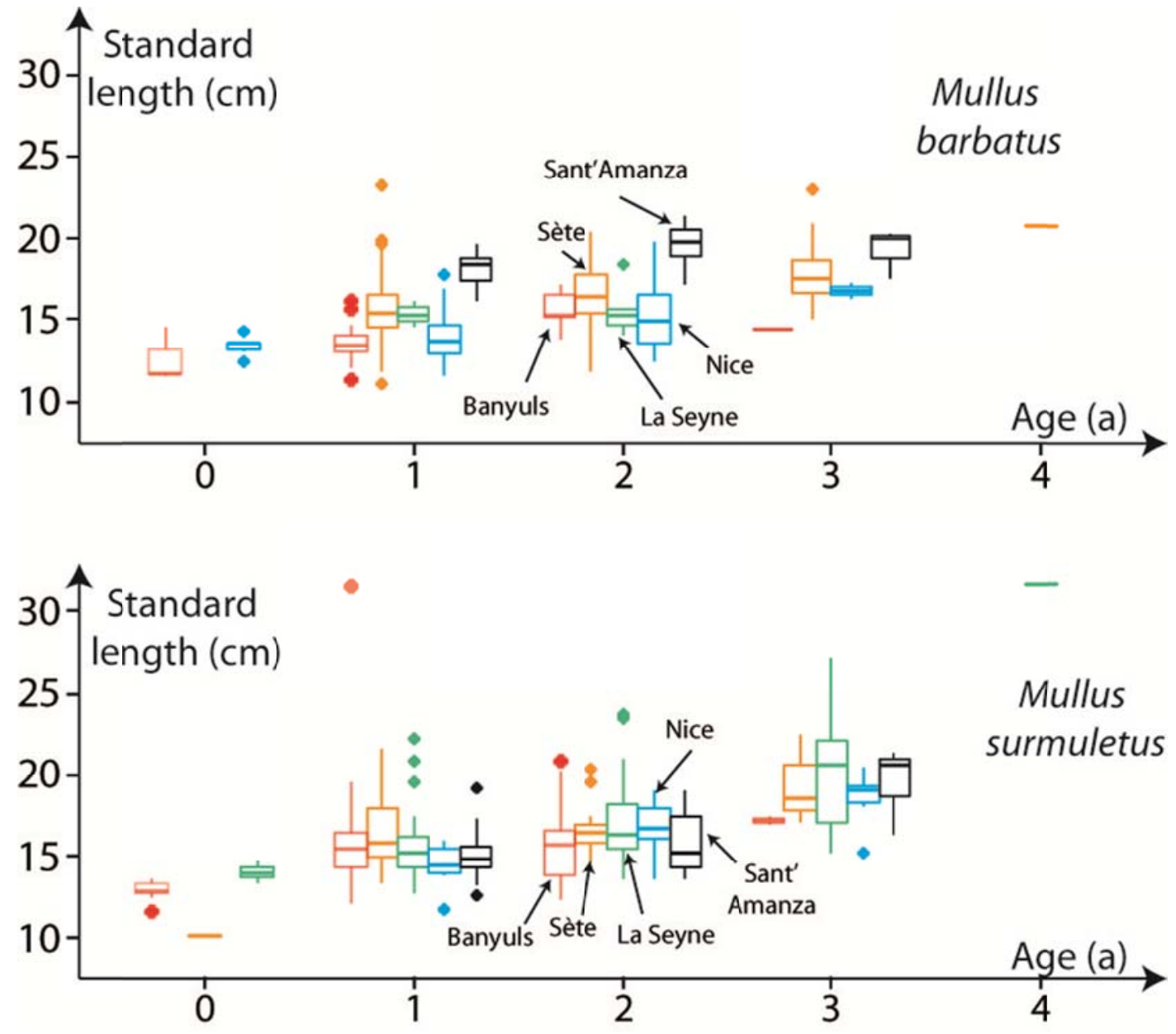
Table S1: Comparison of $\mathrm{Hg}$ concentrations in sediment and caged mussels. Concentrations in the sediment were measured within the Ifremer contamination survey network (ROCCHSED) during 2011 campaign (one measurement at each site) or came from bibliographical references. Concentration in mussels are the means \pm standard deviation of crude values measured during 2000, 2003, 2006, 2009 and 2012 RINBIO campaigns, and uncorrected with condition indices (calculated as the ratio between flesh mass and shell mass for mussels collected in 2012; refer to Andral et al. 2004 for details of the methodology used)

\begin{tabular}{|l|l|c|c|c|c|}
\hline & Banyuls & Sète & La Seyne & Nice & Sant'Amanza \\
\hline Sediment $\left(\mu \mathrm{g} \mathrm{g}^{-1}\right)$ & $0.06^{\mathrm{a}}$ & $0.06^{\mathrm{a}}$ & $\begin{array}{c}1.86^{\mathrm{a}} \\
2.26-3.24^{\mathrm{b}}\end{array}$ & nd & $0.03^{\mathrm{a}, \mathrm{c}}$ \\
\hline $\begin{array}{l}\text { Mussels condition } \\
\text { index }\end{array}$ & 0.13 & 0.15 & 0.10 & 0.09 & 0.09 \\
\hline $\begin{array}{l}\text { Mussel raw Hg } \\
\text { concentration }\left(\mu \mathrm{g} \mathrm{g}^{-1}\right)\end{array}$ & $0.07 \pm 0.02$ & $0.04 \pm 0.01$ & $0.25 \pm 0.01$ & $0.09 \pm 0.03$ & $0.12 \pm 0.06$ \\
\hline
\end{tabular}

a: Ifremer chemical contamination survey network, JF Chiffoleau pers. comm.; b: range of values in the zone of fish sampling, data read on the map of Teissier et al. (2011) ; c: Galgani et al. (2006) 
Table S2: Number of fishes sampled, by species, site and date

\begin{tabular}{|c|c|c|c|c|c|c|c|c|c|c|c|}
\hline \multirow[b]{2}{*}{ Month } & \multicolumn{5}{|c|}{ Mullus barbatus } & \multicolumn{5}{|c|}{ Mullus surmuletus } & \multirow[t]{2}{*}{ Total } \\
\hline & Banyuls & Sant’ Amanza & La Seyne & Nice & Sète & Banyuls & Sant' Amanza & La Seyne & Nice & Sète & \\
\hline June 2012 & 4 & & 6 & 43 & 10 & 29 & & 16 & & & 108 \\
\hline August 2012 & 9 & & & 30 & & 27 & & 13 & & 10 & 89 \\
\hline October 2012 & & 9 & 1 & & & 29 & 10 & 14 & & 21 & 84 \\
\hline December 2012 & & 15 & & & 22 & 33 & 2 & & & 1 & 73 \\
\hline February 2013 & & & & 13 & 17 & 22 & & 10 & 8 & 12 & 82 \\
\hline April 2013 & & & & 11 & 20 & & 38 & 28 & 13 & 1 & 111 \\
\hline June 2013 & & & 2 & 44 & 20 & & & 25 & 3 & 8 & 102 \\
\hline August 2013 & 37 & & 12 & 41 & 32 & 16 & 2 & 9 & 9 & 6 & 164 \\
\hline October 2013 & 4 & & & & 26 & 24 & 25 & & & & 79 \\
\hline December 2013 & 4 & & & 50 & 4 & 22 & 35 & 17 & & 18 & 150 \\
\hline Total & 58 & 24 & 21 & 232 & 151 & 202 & 112 & 132 & 33 & 77 & 1042 \\
\hline
\end{tabular}


Table S3: Results of the comparison of Hg concentrations, with ANOVA. Post-hoc column present the results of LSD post-hoc comparison tests, with letters refering to the sampling sites (Ba: Banyuls; Se: Sète, Ni: Nice, LS: La Seyne; SA: Sant’Amanza), months (F: February, Ap: April, Ju: June, Au: August, O: October, D: December) and years (12: 2012, 13: 2013)

\begin{tabular}{llll}
\hline Parameter & Stat & p-value & Post-hoc \\
\hline Site & $\mathrm{F}_{(4,989)}=82.26$ & $<0.0001$ & $\mathrm{Ba}=\mathrm{Se}<\mathrm{Ni}<\mathrm{LS}<\mathrm{SA}$ \\
Date & $\mathrm{F}_{(9,986)}=6.08$ & $<0.0001$ & $\mathrm{D} 12=\mathrm{Au} 12=\mathrm{Au} 13<\mathrm{O} 12=\mathrm{D} 13=\mathrm{Ju} 13=\mathrm{F} 13=\mathrm{O} 13=\mathrm{J} 12<\mathrm{Ap} 13$ \\
Species & $\mathrm{F}_{(1,986)}=12.03$ & $<0.0001$ & M. barbatus $<$ M. surmuletus \\
Site x Date & $\mathrm{F}_{(25,986)}=12.01$ & $<0.0001$ & \\
Site x Species & $\mathrm{F}_{(4,986)}=1.42$ & 0.225 & \\
Date x Species & $\mathrm{F}_{(9,986)}=2.72$ & 0.006 & \\
\hline
\end{tabular}


Table S4: Parameters of linear regressions between Hg concentration and length (L). Linear relationships were considered to be significant when $r^{2} \geq 0.25$ and $p \leq 0.05$

\begin{tabular}{|l|l|l|l|l|l|l|}
\hline & All sites & Banyuls & Sète & La Seyne & Nice \\
\hline M. barbatus & $\begin{array}{l}\mathrm{Hg}=0.03 \mathrm{~L}-0.06 \\
\mathrm{r}^{2}=0.04 ; \\
\mathrm{p}<0.0001\end{array}$ & $\begin{array}{l}\mathrm{Hg}=0.06 \mathrm{~L}-0.61 \\
\mathrm{r}^{2}=0.18 ; \\
\mathrm{p}<0.0001^{* * *}\end{array}$ & $\begin{array}{l}\mathrm{Hg}=0.06 \mathrm{~L}-0.68 \\
\mathrm{r}^{2}=0.24 ; \mathrm{p}<0.0001^{* * *}\end{array}$ & $\begin{array}{l}\mathrm{Hg}=-0.07 \mathrm{~L}+1.85 \\
\mathrm{r}^{2}=0.03 ; \mathrm{p}=0.21\end{array}$ & $\begin{array}{l}\mathrm{Hg}=0.03 \mathrm{~L}-0.04 \\
\mathrm{r}^{2}=0.03 ; \mathrm{p}=0.01\end{array}$ & $\begin{array}{l}\mathrm{Hg}=3.8310^{-3} \mathrm{~L}+0.25 \\
\mathrm{r}^{2}=0.03 ; \mathrm{p}=0.93\end{array}$ \\
\hline M. surmuletus & $\begin{array}{l}\mathrm{Hg}=0.02 \mathrm{~L}+0.18 \\
\mathrm{r}^{2}=0.02 ; \\
\mathrm{p}^{*} 0.003^{* *}\end{array}$ & $\begin{array}{l}\mathrm{Hg}=0.01 \mathrm{~L}+0.13 \\
\mathrm{r}^{2}=0.14 ; \\
\mathrm{p}=0.014^{*}\end{array}$ & $\begin{array}{l}\mathrm{Hg}=0.01 \mathrm{~L}+0.08 \\
\mathrm{r}^{2}=0.06 ; \mathrm{p}=0.03^{*}\end{array}$ & $\begin{array}{l}\mathrm{Hg}=7.0410^{-3} \mathrm{~L}+0.42 \\
\mathrm{r}^{2}=0.01 ; \mathrm{p}=0.50\end{array}$ & $\begin{array}{l}\mathbf{H g}=\mathbf{0 . 0 9 L}-\mathbf{1 . 0 6} \\
\mathbf{r}^{2}=\mathbf{0 . 2 5} ; \mathbf{p}=\mathbf{0 . 0 0 3}\end{array}$ & $\begin{array}{l}\mathrm{Hg}=-0.01 \mathrm{~L}+0.87 \\
\mathrm{r}^{2}=0.00 ; \mathrm{p}=0.78\end{array}$ \\
\hline
\end{tabular}

